\title{
The length of the distribution channel as a factor of its efficiency
}

\author{
Aleksandra Andjelkovic \\ Faculty of Economics, University of Nis, Nis, Serbia \\ Marija Radosavljevic \\ Faculty of Economics, University of Nis, Nis, Serbia
}

\begin{abstract}
Distribution network is a system of activities that provide transfer of products between producers and final users. It is also known as distribution channel, marketing channel, distribution chain, distribution pipeline, market chain and trade chain. This network has two or more partners, so it has to be coordinated in the direction of order fulfilment and satisfied demand.

As a partnership business network, distribution channels are very important, due to their role in responding to customers' requests. Distribution channels could provide competitive advantage for all partners along the network, through shorter delivery lead time and higher product availability. Although the main purpose of distribution channels is providing continuous flows of products to customers, they should be designed to fill customer's demand with minimum total cost. Determining the right number of facilities and proper locations for distribution network is an essential issue for companies involved in the channel.

The issue of distribution channel's length has become more interesting due to the parallel existence of two different trends. On one hand, there is tendency for reducing number of partners, facilities or stages of distribution channels, with the purpose of avoiding extra expenses, but on the other hand there is a necessity to involve more partners in distribution channel, because that is a way for providing greater market share.

Configuration of distribution channels depends on many factors. These factors have internal or external character. Therefore, the fact that the distribution of the same products in different countries can be performed completely differently is not surprising at all. In this regard, the aim of this papers is to classify the factors that affect the length of the distribution channel. In addition, the paper will also indicate advantages as well disadvantages of both long and short distribution channels. The goal of the analysis of the factors and the way of designing distribution channels, in terms of its length, is to make an adequate decision for increasing efficiency of the distribution network.
\end{abstract}

Keywords

Distribution, channel's length, network, flows, efficiency

\section{Introduction}

Distribution includes a set of operations for transmitting products from manufacturers to final users (Fayaz \& Azizinia, 2016). Similarly, Segetlija, Mesarić \& Dujak (2011) explains distribution as a system of all activities for transferring products between manufacturers and customers. Distribution system therefore assumes coordination of preparation, adequate type and volume of products, at the right time and space, with the purpose to ensure fulfilment of orders and satisfied demand (Segetlija et al., 2011). Distribution operations or activities are, actually, performed inside distribution channel. A distribution channel is linearly ordered by operations in the purpose to achievement physically flow from one to another intermediaries down to the final user (Oklander, 2005; Larina, 2005).

Designing a distribution channel implies some decisions and choices (Szeląg-Sikora \& Rorat, 
2016), concerning the type of channel (direct, indirect), the number of partners involved (one or several), length (long, short), width (wide or narrow), the type of intermediaries (wholesalers, retailers, agents, buyers, individual, etc.). The above mentioned choices influence the distribution system efficiency, so decision about distribution channel structure seems very important (Galkin, 2015).

More precisely, efficiency of distribution system determines the level of its ability to achieve defined goals, higher market share or profitability, or to dominate over competitors (Szeląg-Sikora \& Rorat, 2016). Although the most often used measures for measuring a distribution channel's performance have financial character (revenue, net profit, turnover or logistics costs), nonfinancial measures also become very significant in the conditions of global competition, such as level of customer service or improved customer value. Efficiency of a channel could be measured by ability of each company in channel to minimize costs which are associated with performing necessary channel functions (American Marketing Association, n.d.). It depends not only on internal resources or inputs of each company involved, but also on external resources. The structure of the distribution channel affects the possibility of exploiting both internal and external resources. Therefore, it is in the interest of all partners to design an adequate distribution channel structure.

Channel theory has two orientations: economic and behavioural. Economic orientation has a focus on channel efficiency, with analysing design and structure of the channel, while behavioural orientation is concerned with relationship, cooperation and conflicts between the partners in channels (Da Silva, 2008). In this regard, the involvement of intermediaries between manufacturers and customers can be justified by economic motives, by reducing the transport costs of producers, by economies of scale and with a focus of producers on key competences, but it can also be justified by behavioural motives, or by need for establishing trust-based relationships with minimizing conflicts between channel's partners.

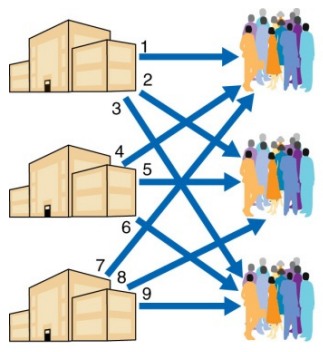

A. Number of contacts without a distributor $M \times C=3 \times 3=9$

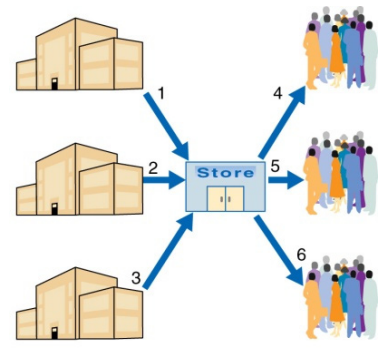

B. Number of contacts with a distributo $M+C=3+3=6$

$$
\text { C. } 7=\text { Manufacturer }
$$

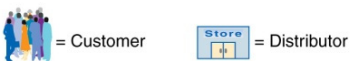

Figure 1 Importance of the distribution in terms of reducing the number of contacts

Source: Chapman, n.d.

Figure 1 shows an increase in the efficiency of the channel by involving an intermediary. However, the number of intermediaries involved in the distribution process between manufacturers and customers can affect the efficiency of the entire channel function in a negative context as well, since the increase in the number of intermediaries affects the increase of the distribution costs. In addition, the emergence of conflicts, which is more certain in case of longer or indirect than in case of shorter or direct distribution channel, can also negatively affect the efficiency of the entire distribution system. In this sense, in this paper the focus is on the analysis of distribution channels in terms of number of intermediaries, highlighting the advantages and disadvantages of long or short channels. In addition, the analysis of different factors (internal and external) will indicate the drivers of distribution channel's length.

\section{Direct or indirect distribution channels' efficiency}

The most common types of distribution network are direct and indirect, with one or more levels of intermediaries (distributor, wholesaler, and retailer). According to this classification, Dent (2011) points to the following structures of distribution: direct - without intermediaries between producer and customers, one-tier distribution with a set of intermediaries between producer and customers, two-tier distribution with two sets of intermediaries (for the purpose of increasing level of services for a wider market area), and multiple-tiered distribution with more than two set of intermediaries. Having in mind the number of intermediaries in the distribution channel or its length, Rushton, Croucher \& Baker, (2014) divide distribution channels into "short" and ,long". According to those authors, length of a distribution channel has direct impact on the 
efficiency of the distribution system through distribution costs and quality of service of each partner of the channel.

Long distribution channels have a multi-tier distribution, and each tier could contain several warehouses and distribution centres, such as warehouses of producers, distribution centres, regional centres, local warehouse etc. Thus, long distribution channels have a lot of loops and connections between them. This is the reason why problems which are usual for distribution channels could be much more serious in long distribution channels (Djafar, Amer \& Lee, 2013). On the other hand, short distribution channel assumes the direct distribution of products to the consumer or a small number of intermediaries, as well as links that need to be managed. In this regard, in comparison with the long distribution channels, the distribution system in this case is much simpler. Success of short distribution channel depends from consumer's behaviour (Fedorko, Bacik \& Gavurova, 2018, p. 1243). The lack of control of the channel and liquidity problems are recognized as key problems and challenges of longer distribution channels. On the other hand, trustbased relationship (Sheffi \& Rice, 2005, p. 45), high level of coordination and exchange of information among partners are characteristics of short distribution channels. It follows that it is much easier to notice problems and manage shorter distribution channels, as well as to detect potential errors and risky situations, on one side, but also hard to manage risky situations due to the greater degree of dependence partners and the inability to respond to unpredictable and changing market demands due to the lack of alternatives (Blome \& Henke, 2009, p. 132), on the other side.

Distribution channels with a large number of intermediaries have a problem with a high level of complexity. This type of distribution networks could have problems concerning coordination and collaboration between partners (Segetlija et al., 2011). According to Hyton (2005), a great number of intermediaries could have a reflection to level of coordination.

Concerning the above mentioned, the authors agree with Hyton (2005) that intermediaries in distribution channels represent a main source of problems. In this sense, long distribution channels are faced with the following problems (Djafar et al., 2013): variability, bottleneck, bullwhip effect, delivery time and distribution costs, and conflicts between intermediaries.
Due to the large number of organizations, activities and facilities, long distribution channels become favourable ground for variability. Sources of variability can exist both on the supply and demand side. Variability on the demand side is a result of incorrect demand forecasting, seasonal character of demand, uncertainty circumstances caused by the lack of information or changes in dynamic market, or customer behaviour (Selim \& Ozkarahan, 2008). Variability of demand directly affects the inventory level, and wrong estimation of demand in terms of excess inventory or stock outs will lead to an increase in the cost of keeping inventories or the cost of lost sales. Variability on the supply side is a result of insufficient production capacities, unreliable warehouse facilities and transportation systems, and inadequate planning and control due to lack of information. When the source of variability is identified, there are following options for absorbing its negative impact: higher inventory level (it will enable avoiding of stock outs, but with increasing keeping inventory costs), development of partnership relations and trust, offering different prices for various delivery times, setting production schedule with customers' requirements. The last two options may be used for make-to-order products.

Bottlenecks in long distribution channels present barriers for continuous product flow and points of weak performance. Bottlenecks are points whose capacities are lower than demand. Those could be seaports, airports, and customs as places of loading and uploading process and as places of intermodal transport. Research in Indonesia from 2005 showed that costs of some companies are higher by $14 \%$ as a result of logistics bottlenecks and especially seaports (Peidro, Mula, Poler \& Lario, 2009). In order to minimize the effects of bottlenecks, distribution channels take the following actions: define priority orders, determine lot size according to available capacity, trade-off between size handling and transport lot.

The bullwhip effect is a result of lack of coordination among partners, because of poor information sharing, inadequate market data, insufficient forecast techniques or other uncertainties (Djafar et al., 2013). Forecasting demand according to demand of previous partner, instead according to demand from point of sale is the major cause of bullwhip effect. Consequences of bullwhip effect are more serious in long distribution channels, due to the great number of intermediaries, so that implies greater deviation in demand between customers and the producers. 
The delivery time is one of the most important indicators of distribution channel efficiency. This indicator directly depends on the number and structure of distribution channels. In terms of delivery time, common aim of all partners in the distribution channel is to minimize it. Beside delivery time, for evaluation of distribution channels success, different costs arising from the distribution process should be analysed, for example: warehouse costs, transportation costs, inventory costs, equipment costs etc. (Andrejić \& Kilibarda, 2015). Long distribution channels have more challenges to face considering that those channels have more storage points and product movements. With an increase in the number of intermediaries, distribution costs increase, too, which eventually leads to increasing the price that the final customer pays (Sharifi, Masoudi \& Javadin, 2013). According to Hesse and Rodrigue (2004) each additional transit day could increase final cost of product approximately by $0.8 \%$.

Also, one of the challenges which are imposed by long channels is conflicts. Conflicts could be a result of a low level of coordination between intermediaries. Incompatible objectives of intermediaries may have negative consequences on coordination and efficiency of the distribution system.

In their study about designing distribution channel for consumer goods, Grant and Banomyong (2010) found a solution for the problem in the case of long distribution channels. Those authors concluded that factors as human resources, suitable distribution infrastructure, implementation of new technologies and ecommerce have a great influence on efficiency growth and reduction of distribution cost. In modern conditions, especially role of information technologies in distribution channels is irreplaceable. Long distribution channels find possibility for eliminating or minimizing consequences of inadequate coordination in implementation of information technology. Beside establishing collaboration and ensuring coordination between partners, importance of information technology grows in the following conditions (Segetlija et al., 2011):

- increased market sensitivity,

- increased number of channel types,

- increased market size,

- wider use of e-commerce,

- internationalization and access to global market.

\section{Drivers of distribution channel's length}

The decision about length of distribution channel is conditioned by numerous factors, both from the internal and external environment. A large number of authors dealt with this issue. However, they usually analysed only one or few factors that could have impact on the length of the channel. Isolating only one or few factors can be a major limitation when deciding about the length of the channel. Some authors analysed only the influence of buying habits on the length of the channel (Bucklin, 1962; Rangan et al., 1992; Frazier and Lassar, 1996), while others observed the impact of the product type on the channel length (Rangan, Menezes \& Maier, 1992; Frazier \& Lassar, 1996; Black, Lockett, Ennew, Winklhofer \& McKechnie, 2002; Liu \& Cui, 2014). Aspinwall (1962) and Miracle (1965) monitored the impact of particular product characteristics on the length of the distribution channel. Bucklin (1966) analysed market decentralization, lot size, assortment, and waiting time as a factors of distribution channel's length. Lilien (1979) was testing impact of product and market factors on the length of distribution channel, on a sample of 125 industrial products.

Designing the optimal length of the distribution channel is conditioned by customer habits, product characteristics, market factors, and factors of the focal company (Da Silva, 2008). The Table 1 shows an overview of the mentioned factors and how they affect the length of the channel.

Table 1 Factors of distribution channels' length

\begin{tabular}{|c|c|c|}
\hline \multirow[t]{2}{*}{ Factors } & \multicolumn{2}{|c|}{ Distribution channel } \\
\hline & Short if: & Long if: \\
\hline \multicolumn{3}{|l|}{ Customer habits } \\
\hline Frequency of purchase & Low & High \\
\hline Purchasing effort & High & Low \\
\hline Rapidly of consumption & Low & High \\
\hline $\begin{array}{l}\text { Significance of } \\
\text { purchase }\end{array}$ & High & Low \\
\hline Waiting time & High & Low \\
\hline \multicolumn{3}{|l|}{$\begin{array}{c}\text { Product } \\
\text { characteristics }\end{array}$} \\
\hline Replacement rate & Low & High \\
\hline Gross margin & High & Low \\
\hline Adjustment & High & Low \\
\hline Searching time & High & Low \\
\hline Unit value & High & Low \\
\hline Product complexity & High & Low \\
\hline Product life-cycle stage & Introduction & Maturity \\
\hline Volatility of demand & High & Low \\
\hline $\begin{array}{l}\text { Brand positioning of } \\
\text { quality }\end{array}$ & High & Low \\
\hline Perishability & Low & High \\
\hline \multicolumn{3}{|l|}{ Market factors } \\
\hline $\begin{array}{l}\text { Target focus on mass } \\
\text { market }\end{array}$ & Low & High \\
\hline $\begin{array}{l}\text { Rate of technological } \\
\text { change }\end{array}$ & High & Low \\
\hline
\end{tabular}




\begin{tabular}{|l|l|l|}
\hline Intensity of competition & Low & High \\
\hline $\begin{array}{l}\text { Geographic } \\
\text { concentration of } \\
\text { market }\end{array}$ & High & Low \\
\hline \multicolumn{1}{|c|}{ Company factors } & & \\
\hline Range of products & Wide & Narrow \\
\hline Order size & Large & Small \\
\hline Market share & Low & High \\
\hline Desire of control & High & Low \\
\hline Retailer investments & Low & High \\
\hline $\begin{array}{l}\text { Number of support } \\
\text { programs }\end{array}$ & Low & High \\
\hline Promotion budget & Low & High \\
\hline Size of the company & Large & Small \\
\hline
\end{tabular}

Beside analysed factors of distribution system length, based on some empirical research conducted in certain countries or regions, it is obvious that context also has impact on it. For instance, the Japanese distribution system is a great example of long and convoluted channel, with a lot of wholesalers (Figure 2). ${ }^{1}$ Papers and studies which analysed Japanese distribution system tried to figure out the reasons for its complexity. One of the reasons of long distribution channels in Japan is small stores (Flath \& Nariu, 1991).

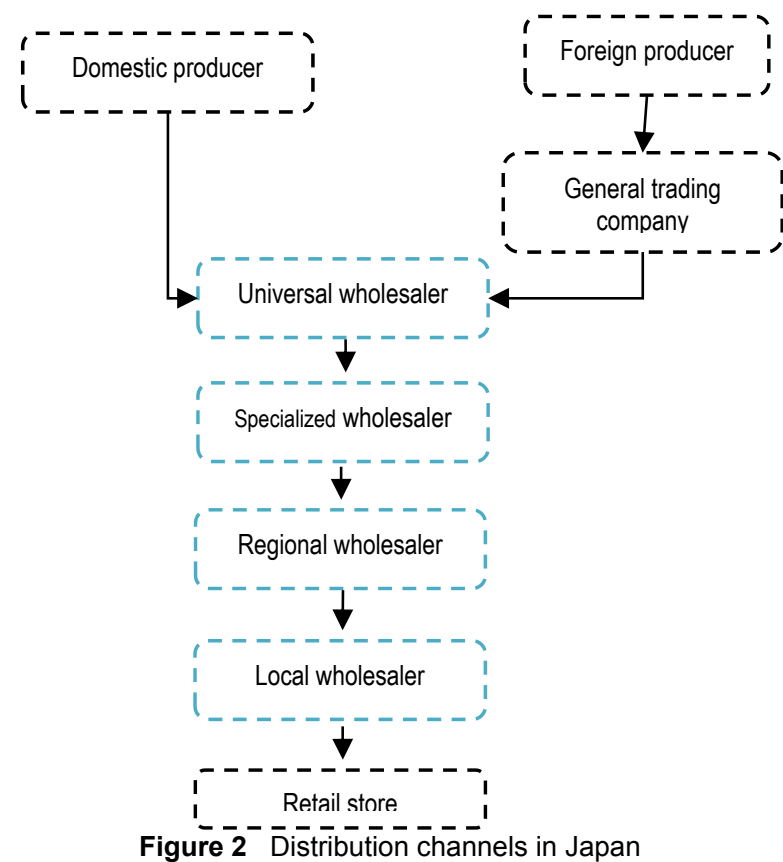

Source: Revised according to Lovreta, Petković \& Končar, 2013, p. 106.

Earlier research showed a great percentage of wholesalers in distribution channels in relation to other intermediaries in Japan. So, percentage of sales from one to other wholesalers in Japan is $41.9 \%$, in United States $24.8 \%$ and $16.2 \%$ for Germany (Flath \& Nariu, 1991). Ubiquity of retail

${ }^{1}$ However, not all distribution channels in Japan are long, with a great number of wholesalers. For example, products stores is also the reason of great number of wholesalers. According to Bucklin (1966), ubiquity of retailer stores in Japan and a lot of wholesale steps have one common point economies on household storage. Both have interest to ensure inventories in close proximity to customers and frequently inventory replenishment. Flath (1990) recognized higher costs of storage in retail stores in comparison to costs of storage in wholesale centres and short geographic distance between point of production and point of consumption, as reasons for ubiquity of retail stores in Japan.

A survey conducted in February and March 2010 involving 486 customers of cranes from the EMEA (Europe, Middle East and Africa) and APAC (Asia and Pacific) cranes in the context of testing the importance of direct and indirect distribution channels for achieving annual profitability, buyer satisfaction and buyer loyalty, has shown a greater importance of indirect channels in terms of achieving greater profitability. However, by analysing customers' satisfaction and loyalty, it has been found that greater satisfaction and loyalty in this type of product can be achieved by using direct channels. The key reason is the establishment of solid collaborative relationships through a direct channel that are the basis for achieving a greater degree of satisfaction and then consumer loyalty (Rambocas, Meneses, Monteiro, $\&$ Brit, 2015).

Number of intermediaries could be changed during the life cycle of the product. For example, at the beginning of business in the United States telephone service provider AirTouch Cellular used agents and wholesalers to sell telephones and service. Involving agents and wholesalers in distribution channels was justified by the necessity of installing the phone properly. So, installing the phone was a good part of added value of intermediaries. The emergence of mobile phones has reduced the importance of agents and wholesalers, especially in the domain of installing the phone, which was their key competence (Frazier, 1999).

Due to the fact that both models of distribution channel have pros and cons, usually there is a need for adopting a hybrid approach, or combining direct and indirect channels, as well as exploiting the benefits of both approaches.

as motor vehicles and electric appliances have a relatively few intermediaries, and also wholesalers. 
By involving an intermediary in the distribution channel, cost of inventory holding will increase, but at the same time that will reduce the physical distance and lead time to the customers. As ways for reducing transportation and logistics cost long distribution channels use: various alternatives of vehicles (less than truck load/LTL, full truck load/FTL, train, sea vehicles etc.) or warehouses (as distribution centre or transit-terminal consolidation). By using various facilities, long distribution channels could provide more options for warehousing and transport in small or large quantity, depending on the size and number of orders, in order to avoid possibility for lost demand.

Choosing direct channels is justified by cost savings and establishing of direct contacts with the market. "Expensive" intermediaries are eliminated through the company's direct channels. In addition, producers expect to achieve better relationships with customers and a greater degree of loyalty and trust, through direct channels. Apple is a great example exploiting the benefits of direct channels, since this company has a many-branched retail network. Also, Tesla has shown that it can successfully market cars from their own Tesla showrooms.

The choice of long channels allows to producers focus on key competencies, provide better market coverage and lower physical distance from customers. More and more combinations of direct and indirect distribution channels are present in modern conditions. In this way, producers want to take advantages of both one and the other way of placing products on the market. For example, Nike sells its products through several tens of thousands of retailers around the world. Beside indirect channels, Nike has direct channels: Nike.com and more than 1000 flagship and outlet stores. In 2017 through direct channels Nike realized $28 \%$ of total sales (Statechi, n.d.).

\section{Methodology and results of the research}

In order to get a picture about the domination of certain type of distribution channels in the Republic of Serbia, a pre-research was conducted. In the focus of this research are companies that operate in the Republic of Serbia, from the food industry. The research framework represents the systematisation of factors of distribution channels' length presented in Table 1 . The objective of the research is to identify factors that have dominant role in making decision on distribution channels' length. Therefore, the research hypothesis is formulated in the following way: There is statistically significant difference between the factors indicated as drivers of distribution channels' length.

The evaluation of factors impact on decision about the distribution channels' length was done by top managers of the observed companies. The impact of each factors was evaluated based on the Likert scale (five point scale, where 1 means that the factor does not have any impact, while 5 means that the factor has great impact on decision about the distribution channels' length). Bearing in mind the fact that the sample is rather small (24 enterprises), the authors consider the results of analysis as informative and as an opportunity for identification of some new factors that should be included into evaluation and analysis. Data were collected by questionnaire, comprising of some general questions (type of industry, company's size, capital origin and so on) and questions concerning 27 factors of distribution channels' length. However, since reliability analysis, based on Cronbah's Alpha test, has shown that some variables (factors) should be excluded from further analysis, the actual number of the observed factors is 20 (Cronbah's alpha based on standardized items is 0.825$)$. The data have been analysed by using usual statistical methods (descriptive statistics, ANOVA, factor analysis). In order to create an image about the estimated impact of observed factors on distribution channels length, they are observed at the group level (customer habits, product characteristics, market factors, company factors), and detailed analysis is planned after this pre-research. The results of descriptive analysis are presented in Table 2. Data indicate that customers' habits (2.51) and company factors (2.29) are the most important, from managers' perspective.

Table 2 Descriptive statistics

\begin{tabular}{|l|r|r|r|r|r|}
\hline & $\mathrm{N}$ & Minimum & Maximum & Mean & $\begin{array}{c}\text { Std. } \\
\text { Deviation }\end{array}$ \\
\hline CU & 24 & 1.00 & 3.50 & 2.5104 & .54911 \\
\hline PR & 24 & 1.17 & 3.50 & 2.0069 & .70622 \\
\hline MA & 24 & 1.00 & 3.67 & 2.1806 & .81043 \\
\hline CO & 24 & 1.00 & 3.17 & 2.2986 & .53383 \\
\hline
\end{tabular}

In order to evaluate whether the difference of the grouped factors' impact on distribution channel length is statistically significant, ANOVA was used. Based on the results from Table 3 , it is obvious that there is statistically significant difference of the observed factors' impact. 
Therefore, it might be said that from managers' point of view some factors are more important when deciding about distribution channel's length.

Table 3 ANOVA

\begin{tabular}{|l|r|r|r|r|r|}
\hline & $\begin{array}{c}\text { Sum of } \\
\text { Squares }\end{array}$ & \multicolumn{1}{|c|}{ df } & $\begin{array}{c}\text { Mean } \\
\text { Square }\end{array}$ & \multicolumn{1}{c|}{ F } & Sig. \\
\hline $\begin{array}{l}\text { Between } \\
\text { Groups }\end{array}$ & 3.218 & 3 & 1.073 & 2.463 & .007 \\
\hline $\begin{array}{l}\text { Within } \\
\text { Groups }\end{array}$ & 40.067 & 92 & .436 & & \\
\hline Total & 43.285 & 95 & & \multicolumn{2}{|c|}{ Source: Authors } \\
\hline
\end{tabular}

Even though some factors are considered more important than the others, it might be useful to see how individual factors are connected. For this purpose, cluster analysis is used and precisely dendrogram (Figure 3 ), as a diagram that shows the hierarchical relationship between objects (in this case created as an output from hierarchical clustering).

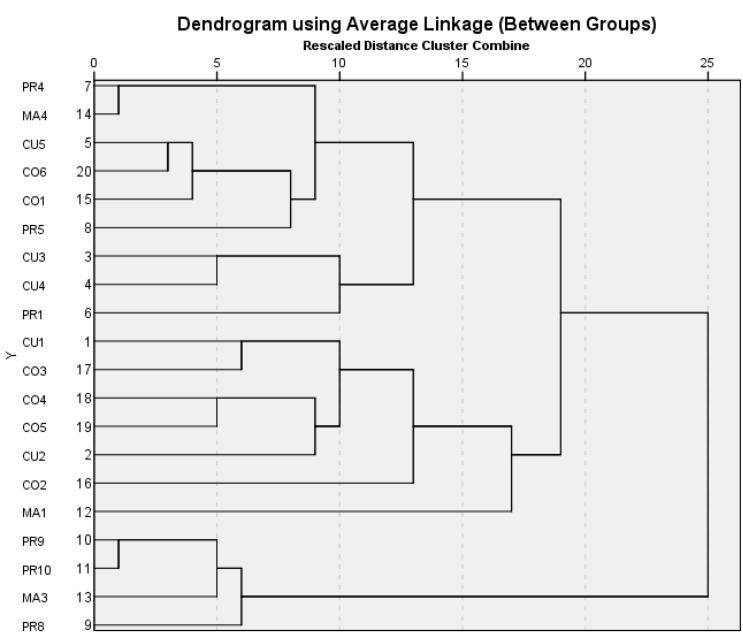

Figure 3 Dendrogram - hierarchical relationship between the factors

Source: SPSS software output (IBM SPSS 22)

According to the dendrogram, factors that are identified as the most important for determining the distribution channels length are at the same time closely connected factors. Therefore, for this level of the analysis, it may be concluded that customers' habits and company factors have decisive impact on deciding about the distribution channel's length.

\section{Conclusion}

Solving the dilemma of choosing direct or indirect distribution channels depends on defining an adequate model. It seems that the key issue in selecting one or the other distribution model is to accept trade-off between market coverage and costs concerning holding inventories. Long distribution channels will increase market coverage but also will provoke higher inventory costs.

The results of the research, partly presented in the paper, do not offer one precise solution about the type of distribution channels that should be chosen by analysed companies. However, they indicate the groups of factors that are considered as more influential on distribution channel's length in comparison to the others. Based on descriptive and ANOVA statistics it is obvious that the dominant groups of factors refer to customers' habits and company factors.

Certainly, the significant limitation of the research certainly is the sample size. Beside this one, another limitation concerns the analysis of distribution channels efficiency, since this would give an opportunity to analyse the impact of certain factors, not only on the length of distribution channels, but also on their efficiency.

Considering the number of papers and studies on the length of the distribution channel, it seems that this is a very interesting area. However, there is still no holistic approach that will define more detailed and precise recommendations when deciding on channel's length selection. In addition, the emergence of hybrid channels has the objective to overcome disadvantages of short and long distribution channels. Further research may be focused on understanding channels' design, in the sense of companies' freedom in choosing a channels' length or adapting to it and recognizing some other factors that could have an influence on distribution length, preferably by Delphi method. Since it is pointed out in the paper that establishing collaboration and ensuring coordination between partners is greatly affected by information technology, it is obvious that the importance of information technology is growing and that it should definitely be included into the list of factors determining the length of distribution channels that provides customers' satisfaction and channels' efficiency at the same time.sm

\section{References}

American Marketing Association (n.d.). Retrieved $18^{\text {th }}$ March 2019 from www.marketingpower.com

Andrejić, M. \& Kilibarda, M. (2015). Distribution Channels Selection Using PCA-DEA Approach. International Journal for Traffic and Transport Engineering, 5(1), 7481

http://dx.doi.org/10.7708/ijtte.2015.5(1).09 
Aspinwall, L. V. (1962). The characteristics of goods theory. In William, L. \& Eugene, J. K. (Eds.), Managerial marketing: Perspectives and viewpoints (pp. 633-643). Homewood, IL: Richard D. Irwin, Inc.

Black, J. N., Lockett, A., Ennew, Ch., Winklhofer, H. \& McKechnie, S. (2002). Modelling consumer choice of distribution channels: an illustration from financial services. International Journal of Bank Marketing, 20 (4), 161-173 https://doi.org/10.1108/02652320210432945

Blome, C. \& Henke, M. (2009). Single versus Multiple Sourcing: A Supply Risk. In Zsidisin, G. \& Ritchie, B. (Eds.) Supply Chain Risk: A Handbook of Assessment, Management, and Performance, (pp. 125-136). New York: Springer. https://doi.org/10.1007/978-0-387-79934-6 8

Bucklin, L. P. (1966). A Theory of Distribution Channel Structure. Berkeley: IBER Special Publications.

Bucklin, L.P. (1962). Retail Strategy and the Classification of Consumer Goods. Journal of Marketing, 27 (1), 5055.

https://doi.org/10.1177/002224296302700110

Chapman, (n.d.). Marketing Channels and Supply Chain Management, Retrieved $15^{\text {th }}$ February 2020. from https://www.slideserve.com/jacquelinechapman/marketing-channels-and-supply-chainmanagement

Da Silva, A. M. (2008). Distribution Channel Structure: An Overview of Determinants. Revela - Periódico de Divulgação Científica da FALS.

Dent, J. (2011). Distribution Channel: Understanding and Managing Channels to Market. Second ed. London: Kogan Page.

Djafar, W., Amer, Y. \& Lee, S. H. (2013). A Review on Long Distribution Channel's Problems. International Journal of Materials, Mechanics and Manufacturing, 1 (1), 6064.

https://doi.org/10.1016/j.promfg.2015.07.089

Fayaz, R. \& Azizinia, M. (2016). Current challenges in distribution channels of cultural goods and services. Marketing and Branding Research, 3, 75-85. https://doi.org/10.19237/MBR.2016.01.07

Fedorko, I., Bacik, R. \& Gavurova, B. (2018). Technology acceptance model in e-commerce segment. Management \& Marketing - Challenges for the Knowledge Society, 13 (4), 1242-1256. https://doi.org/10.2478/mmcks-2018-0034

Flath, D. \& Nariu, T. (1991). The Complexity of Wholesale Distribution Channels in Japan. Centre on Japanese Economy and Business, Graduate School of Business, Columbia University.

Flath, D. (1990). Why Are There So Many Retail Stores in Japan? Japan and the World Economy, 2, 365-386. https://doi.org/10.1016/0922-1425(90)90017-M

Frazier, G. L. \& Lassar, W. M. (1996). Determinants of Distribution Intensity. Journal of Marketing, 60 (4), 3951. https://doi.org/10.1177/002224299606000405

Frazier, G. L. (1999). Organizing and Managing Channels of Distribution. Journal of the Academy of Marketing Science, 27 (2), 226-240. https://doi.org/10.1177/0092070399272007

Grant, D. B. \& Banomyong, R. (2010). Design of closedloop supply chain and product recovery management for fast-moving consumer goods. Asia Pacific Journal of Marketing, 22 (2), 232-246. https://doi.org/10.1108/13555851011026971

Hesse, M. \& Rodrigue, J. P. (2004). The transport geography of logistics and freight distribution. Journal of Transport Geography, 12 (3), 171-184.

https://doi.org/10.1016/j.jtrangeo.2003.12.004

Hyton, P. (2005). The impact of logistics on retailing and physical distribution. International Journal of Retail \& Distribution Management, 19, 91-120.

Larina P. P. (2005). Logistics: Textbook. Donetsk: Era.

Lilien, G. L. (1979). Exceptional Paper Advisor 2: Modeling The Marketing Mix Decision For Industrial products. Management Science. 25 (2), 117-210. https://doi.org/10.1287/mnsc.25.2.191

Lovreta, S., Petković, G. \& Končar, J. (2013). Kanali marketinga. Beograd: Ekonomski fakultet, Univerzitet u Beogradu.

Miracle, G. E. (1965). Product characteristics and marketing strategy. Journal of Marketing, 29 (1), 18-24

Oklander, M. A. (2005). Logistics: Textbook. Kiev: Foreign Trade.

Peidro, D., Mula, J., Poler, R. \& Lario, F. C. (2009). Quantitative models for supply chain planning under uncertainty: a review. The International Journal of Advanced Manufacturing Technology, 43 (3-4), 400420.

https://doi.org/10.1007/s00170-008-1715-y

Rambocas, M., Meneses, R., Monteiro, C. \& Brit, P. Q. (2015). Direct or indirect channel structures. Evaluating the impact of channel governance structure on export performance. International Business Review, 24 (1), 124-132. http://dx.doi.org/10.1016/j.ibusrev.2014.07.002

Rangan, V. K., Menezes, M. A. J. \& Maier, E. P. (1992). Channel Selection for New Industrial Products: A Framework, Method and Application. Journal of Marketing, 56 (3), 69-82. https://doi.org/10.1177/002224299205600305

Rushton, A., Croucher, P. \& Baker, P. (2014). The Handbook of Logistics and Distribution Management Fifth ed. London: Kogan Page Limited.

Segetlija, Z., Mesarić, J. \& Dujak, D. (2011). Importance of Distribution Channels - Marketing Channels - For National Economy. In Pavlović Križman, D. \& Benazić, D. (Eds) Proceedings of the 22nd CROMAR Congress Marketing Challenges in New Economy (pp. 785-809). Pula, Croatia.

Selim, H. \& Ozkarahan, I. (2008). A supply chain distribution network design model: An Interactive fuzzy goal programming-based solution approach. International Journal Advance Manufacture and Technology, 36 (3-4), 401-418. https://doi.org/10.1007/s00170-006-0842-6

Sharifi, K., Masoudi, M. \& Javadin, S. R. (2013). Network model of production and distribution of goods in Iran. Quarterly Journal of Business Administration Research, 4 (7), 105-121.

Sheffi, Y. \& Rice, J. B. (2005). A Supply Chain View of the Resilience Enterprises. MIT Sloan Management Review, 47 (1), 41-48.

Stratechi (n.d.). Distribution Strategy. Retrieved $2^{\text {nd }}$ April 2019. from https://www.stratechi.com/distributionstrategy/

Szeląg-Sikora, A. \& Rorat, J. M. (2016). Performance of Distribution Channels Shown on the Example of Company Specialising in Meat Processing. Logistics and Transport, 29 (1), 19-24. 


\section{$\square$ Correspondence}

Aleksandra Andjelković

Faculty of Economics, University of Nis

Trg kralja Aleksandra Ujedinitelja 11, 18000, Niš, Serbia

E-mail: aleksandra.andjelkovic@ekonomski.rs 